\title{
PERAN DAN KEWENANGAN PROFESI PENUNJANG PASAR MODAL (NOTARIS) DALAM MENGHADAPI ERA GLOBALISASI ${ }^{*}$
}

\author{
Elvira Fitriyani Pakpahan ${ }^{1},{ }^{*}$ Vivi Prisilla ${ }^{2}$, Dicky $^{3}$, Yuni Adriana Malau ${ }^{4}$ \\ Fakultas Hukum, Universitas Prima Indonesia Medan, \\ 1e-mail: elvirapakpahan@unprimdn.ac.id \\ 2e-mail: viviprisilla97@ gmail.com* \\ 3e-mail: dickyliee08@gmail.com \\ ${ }^{4}$ e-mail: yunyunmalau@gmail.com
}

\begin{abstract}
This study aims to examine the legal arrangements for the role and authority of the capital market supporting profession in the face of globalization, namely the notary public. Notary public is a public official who has the authority to make a contract deed or decision required by law to be made in confirmed documents. The position of a notary is regulated in Law No. 30 of 2004 which states that a notary public is the authorized official to make an authentic deed and other authorities. This study uses a normative juridical method that is analytical descriptive. The notary is authorized to make authentic deeds about all agreements, deeds, and stipulations that are required by legislation and / or that are desired by the parties concerned to be stated in the authentic deed. In addition, the notary must also ensure the certainty of the date of making the deed, keep the deed, give the grosse, copy and quote the deed, all of it as long as the making of the deeds are not also assigned or excluded to other officials.
\end{abstract}

Keywords: Notary; Capital Market; Globalization Era.

\begin{abstract}
Abstrak
Penelitian bertujuan melakukan pengkajian atas pengaturan hukum untuk peran dan kewenangan profesi penunjang pasar modal yaitu notaris di dalam menghadapi era globalisasi. Notaris juga merupakan pejabat publik yang memiliki wewenang dalam membuat akta kesepakatan kontrak atau keputusan yang diharuskan oleh hukum untuk dibuat dalam dokumen yang dikonfirmasi. Undang-undang yang mengatur tentang jabatan notaris diatur dalam: UU No 30 Tahun 2004 notaris yang berisi "notaris adalah pejabat umum yang berwenang untuk membuat akta otentik dan kewenangan lainnya" yang sebelumnya merupakan pergantian dari UU tahun 2014 No 2. Penelitian menggunakan metode yuridis normatif yang bersifat deskriptif analitis, kewenangan notaris diatur dalam UU No 30 Tahun 2004 tentang kewenangan notaris yang berisi “ Notaris berwenangan dalam pembuatan akta otentik tentang semua perjanjian, perbuatan, dan ketetapan yang diharuskan peraturan perundang undangan dan/atau yang diinginkan oleh yang berkepentingan untuk dinyatakan dalam akta otentik, menjamin kepastian tanggal pembuatan akta, menyimpan akta, memberikan grosse, salinan dan kutipan akta, semuanya itu sepanjang pembuatan akta-akta itu tidak juga ditugaskan atau dikecualikan kepada pejabat lain.
\end{abstract}

Kata Kunci : Notaris; Pasar Modal; Era Globalisasi

\footnotetext{
* Naskah diterima: 23 Februari 2020, direvisi: 19 Maret 2020, disetujui untuk terbit: 26 Maret 2019

Doi: $10.3376 /$ jch.v5i2.239
} 
Elvira Fitriyani Pakpahan, Dkk: Peran Dan Kewenangan Profesi Penunjang Pasar...

\section{PENDAHULUAN}

Notaris merupakan pejabat umum yang memang terdaftar di Otoritas Jasa Keuangan (OJK) yang berwenangan untuk membuat akta autentik. (Prana, 2019) karena semua kegiatan hukum perdata tidak akan lepas dari peranan notaris maka notaris memiliki peran penting yang sangat luas. Menurut UUJN juga termasuk dalam ruang lingkup undang-undang dan beserta peraturanperaturan yang organik, karena mengatur tentang suatu jabatan notaris. Materi apa saja yang diatur di dalamnya juga termasuk di dalam hukum publik, sehingga ketentuan-ketentuan yang ada terdapat di dalamnya adalah merupakan peraturan-peraturan yang bersifat memaksa.

Notaris juga merupakan kaki tangan dari pemerintah yaitu Negara telah mempercayakan sebagian urusan atau tugas Negara kepada notaris, khususnya di bidang hukum perdata dan dengan hanya satu satunya wewenang untuk membuat akta kesepakatan kontrak atau keputusan yang diharuskan oleh hukum untuk diformulasikan dalam dokumen yang dikonfirmasi dan bertanggung jawab juga untuk mengatur tanggal akta, memberikan grosse yang sah atau salinan dari kutipan sebagian, asalkan akta tersebut tidak ditugaskan sepenuhnya kepada pejabat publie lainnya dan hanya tugas penting/eksklusif dari notaris. (Prana, 2019)

Pasar modal diartikan juga menjadi pasar untuk berbagai instrument keuangan atau sekuritas jangka panjang yang tentu saja dapat diperjualbelikan, baik dalam bentuk hutang maupun modal sendiri, baik yang diterbitkan oleh perusahaan swasta maupun pemerintahan. (Prana, 2019) Pasar modal juga memiliki peran yang sangat penting dalam hal perekonomian suatu Negara. (Makarim, 2011)

Pasar modal merupakan juga memperjualbelikan semua instrument keuangan jangka panjang, baik yang merupakan surat utang obligasi, saham, reksa dana, dan Berbagai instrument yang lainnya. (Prana, 2019) Perusahaan yang melakukan kegiatan di dalam pasar modal membutuhkan jasa profesi yang dapat menjadi penunjang pasar modal. Profesi yang menjadi penunjang pasar modal adalah merupakan sebuah lembaga/perusahaan yang sangat diperlukan untuk dijadikan sebagai salah satu mitra emiten dalam hal mengadakan kegiatan penawaran umum. Untuk menjadi profesi penunjang pasar modal, lembaga/perusahaan harus pasti telah tercatat dan terdaftar pada Badan Pengawas Pasar Modal dan beserta Lembaga Keuangan (Bapepam-LK), yang sekarang sudah diambil alih oleh Otoritas Jasa Keuangan yang telah disingkat menjadi OJK. (Prana, 2019)

Pasar modal adalah pasar yang dimana diterbitkan dan serta diperdagangkan atau di perjual belikan surat-surat berharga jangka panjang, yang khususnya obligasi dan atau saham sebagaimana halnya di dalam pasar uang maka pasar modal dapat juga diartikan 
dalam lingkup lokal regional dan nasional karena menyangkut dana-dana jangka panjang dan maka dengan itu pasar modal mengandung pengertian atau makna Modal ekonomi. karena Danadana yang dihasilkan melalui penerbitan instrument kredit oleh dunia usaha dan perorangan diinvestasikan kedalam persediaan maupun ke dalam persediaan ataupun harta tetap. (Makarin, 2011)

Pasal 1 angka 1 nomor 2 tahun 2014 Undang-undang Republik Indonesia tentang Perubahan atas Undang-undang Republik Indonesia tentang Jabatan Notaris (UUJN) Nomor 30 tahun 2004, menyatakan bahwa hal yang disebut dengan Notaris adalah pejabat umum yang memiliki kewenangan untuk membuat akta autentik dan memiliki pastinya kewenangan lainnya sebagaimana yang dimaksud dalam Undang-undang ini maupun berdasarkan undang-undang lainnya.

Menurut Pasal 15 Undang-undang Nomor 30 Tahun 2004 tentang Jabatan Notaris (UUJN) berisi:

Notaris berwenang membuat akta otentik mengenai semua perbuatan, perjanjian dan ketetapan yang diharuskan oleh peraturan perundang undangan dan/atau yang dikehendaki oleh yang berkepentingan untuk dinyatakan dalam akta otentik, menjamin kepastian tanggal pembuatan akta ,menyimpan akta, memberikan grosse, salinan dan kutipan akta, semuanya itu sepanjang pembuatan akta-akta itu tidak juga ditugaskan atau dikecualikan kepada pejabat lain atau orang lain yang ditetapkan oleh undang-undang.
Kewenangan pokok dan notaris yang berdasarkan UUJN yaitu membuat atau menghasilkan akta otentik. Akta merupakan sebuah surat bukti yang diadakan sebagai akta suatu pembuktian, di zaman yang semakin modern atau maju ini akan semakin penting karena fungsi sebuah akta yaitu sebagai dokumen yang tertulis dan yang dapat memberikan suatu bukti akan peristiwa hukum yang menjadi dasar dari hak maupun perikatan. (Prana, 2019)

Selain kewenangan yang diutamakan tadi, notaris juga pastinya akan diberikan wewenangan untuk memberikan penyuluhan yaitu hukum terhadap pihakpihak yang pastinya terlibat di dalam suatu kegiatan transaksi, khususnya jika itu mengenai syarat-syarat dan ketentuan yang diharuskan dipenuhi oleh seluruh pihak yang terlibat di dalam suatu transaksi yang akan di notarilkan, sehingga akan terhindarkan dari segala kemungkinan transaksi tersebut dilaksanakan dengan keadaan yang akan atau dapat batal demi hukum dan atau yang dapat di mintakan pengajuan pembatalan di depan pengadilan. (Makarim, 2011) Kewenangan untuk memberikan penyuluhan hukum ini diinterpretasikan di pasal 15 ayat (2) huruf f UUJN yang berbunyi:

"Notaris berwenang pula dalam hal memberikan penyuluhan hukum sehubungan dengan kegiatan pembuatan akta"

Undang-undang Pasar Modal yaitu profesi notaris telah ditunjukkan yaitu sebagai salah satu profesi yang untuk 
Elvira Fitriyani Pakpahan, Dkk: Peran Dan Kewenangan Profesi Penunjang Pasar...

menjadi penunjang pasar modal. Peran utama profesi ini atau profesi penunjang pasar modal pada umumnya adalah membantu emiten dalam proses untuk go public dan dengan memenuhi persyaratan mengenai keterbukaan yang sifatnya terus menerus. (Prof Faisal, 2013)

Penunjukan Notaris yang sebagai profesi penunjang pasar modal dinyatakan di dalam, Undang-Undang no 8 tahun 1995 pasal 64 ayat 1 yang menyatakan tentang pasar modal (UUPM), yang juga menyatakan bahwa profesi penunjang pasar modal tersebut terdiri dari:

1. Akuntan

2. Konsultan Hukum

3. Penilai

4. Notaris

5. Dan Profesi lainnya yang sesuai

Semua Profesi Penunjang Pasar Modal yaitu yang termasuk notaris wajib menaati semua kode etik maupun standar profesi yang telah ditetapkan oleh asosiasi profesi masing-masing sepanjang itu semua tidak akan bertentangan dengan UUPM ataupun peraturan pelaksanaannya. (Nasarudin, 2004)

Kegiatan usaha yang ada di bidang Pasar Modal Notaris wajib untuk memberikan pendapatnya ataupun penilaian yang mandiri . Pasar Modal juga merupakan tempat bagi perusahaan untuk mencari dana dan sarana investasi bagi para masyarakat (investor)yang dimana di dalamnya pasti terdapat transaksi penawaran umum maupun perdagangan efek dari suatu perusahaan publik (emiten). (Nasarudin, 2004)
Pasal 1 angka 13 Undang-undang tahun 1995 nomor 8 tentang pasar modal memiliki pengertian yaitu:

Pasar modal yang lebih detail maupun spesifik, yaitu kegiatan yang sangat bersangkutan dengan penawaran umum maupun perdagangan efek, perusahaan publik yang ada kaitannya dengan efek yang diterbitkan, serta lembaga maupun profesi yang memang berkaitan dengan efek".

Era Globalisasi juga telah membawa dampak yang bersifat multi aspek karena berkaitan dengan bidang ekonomi, hukum sosial politik dan keamanan, hal ini, membawa implikasi terhadap pertumbuhan dan perkembangan masyarakat menyangkut pemenuhan kebutuhan masyarakat global regional dan nasional yang berdimensi mengenai kebersamaan berkelanjutan dan ketercakupan Pasar modal memiliki fungsi yang strategis dan pentingnya pasar modal membuat pemerintah amat berkepentingan atas perkembangan dan kemajuan pasar modal, karena berpotensi untuk menghimpun dana secara masif, sehingga dapat dimanfaatkan untuk kegiatan memperbesar volume pembangunan. (Nasarudin, 2004)

Dalam Common Law maupun Civil Law sesuai dengan perkembangan teknologi, Notaris juga berperan dalam semua transaksi elektronik yang melalui via cyberspace. Namun konsep ini di Indonesia ini memang masih dalam tahap perdebatan, walaupun secara teknologi memungkinkan semua peranan notaris yang secara online maupun remote, 
namun dengan secara hukum hal itu malah seakan tidak dapat dilakukan. Maka dari itu fungsi beserta peranan notaris baik dalam konteks transaksi maupun transaksi elektronik dapat menjadi sangat penting untuk dikaji secara sangat mendalam, agar para notaris yang ada di Indonesia dapat memiliki peran secara global. (Soediro, 2017)

Penelitian ini pun akan selalu melihat bagaimana Fungsi dan perananan yang ada di dalam notaris maupun di alam penyelenggaraan jasa sertifikat yang bersifat elektronik yang ada di dalam beberapa Negara, serta bagaimana upaya agar dapat mengatasi berbagai hambatan yuridis yang ada dan yang berkaitan dengan semua kewenangan notaris itu, supaya para notaris di Indonesia mendapatkan peran yang sebagaimana mestinya. (Hasan, 1998)

Lawewnce Leff mengemukakan bahwa hal dikonsepkan oleh ABA dengan "Cybernotary" yaitu seorang yang mempunyai pastinya kemampuan spesialisasi di dalam bidang hukum dan maupun computer. Fungsinya yaitu untuk dipersepsikan sebagaimana mestinya dan layaknya para Notaris latin di dalam hal memfasilitasikan suatu transaksi yang bersifat internasional. (Makarim, 2011)

\section{METODE PENELITIAN}

Jenis penelitian di dalam jurnal ini adalah Penelitian yang menggunakan jenis metode Yuridis Normative yang bersifat deskriptif analitis. Supaya dapat diketahui apa saja peran dan kewenangan profesi penunjang pasar modal notaris dalam era globalisasi.

\section{HASIL DAN PEMBAHASAN}

\section{Peran Dan Kewenangan Profesi Penunjang Pasar Modal Notaris Dalam Era Globalisasi}

Untuk mengetahui dan menjelaskan apa saja yang termasuk degan yang akan dibahas di dalam penulisan penelitian ini maka kiranya diperlukan agar kita terlebih dahulu mengetahui hal-hal yang sebagai berikut:

\section{1) Notaris}

Dalam Pasal 1 ayat 1 UUJN yang dimaksudkan sebagai Notaris adalah pejabat umum yang memiliki wewenang untuk membuat akta autentik dan serta kewenangan lainnya sebagaimana seperti yang dimaksudkan di dalam Undangundang. Sedangkan di dalam Peraturan Jabatan Notaris yang ada di dalam pasal 1 yang dimaksudkan sebagai Notaris adalah merupakan pejabat umum yang berwenang untuk membuat suatu Akta Autentik mengenai semua hal perbuatan, perjanjian, dan penetapan yang diharuskan oleh suatu peraturan yang umum ataupun oleh yang berkepentingan hendaknya dinyatakan dalam suatu akta autentik, agar menjamin kepastian tanggalnya, menyimpan surat aktenya dan memberikan grosse (Jabatan Notaris, 2004), salinan dan beserta dengan kutipannya, semuanya itu sepanjang pembuatan akte tidak juga ditugaskan ataupun dikecualikan kepada suatu pejabat maupun orang lain. 
Elvira Fitriyani Pakpahan, Dkk: Peran Dan Kewenangan Profesi Penunjang Pasar...

\section{2) Pasar Modal}

Pasar modal merupakan bidang usaha perdagangan yang mengatur tentang surat-surat berharga seperti saham, sertifikat, saham dan serta obligasi. Dalam pengertiannya seperti yang dapat terlihat di dalam praktekprakteknya di Negara-negara yang bersifat maju perdagangan efeknya sesungguhnya juga merupakan suatu kegiatan perusahaan swasta. Motif utamanya yaitu terletak pada suatu masalah kebutuhan bermodal bagi perusahaan yang untuk ingin lebih memajukan usahanya dengan menjual sahamnya kepada para pemilik uang maupun investor yang baik berasal dari golongan yang ada maupun lembagalembaga usaha

Pasar modal adalah pasar yang dimana diterbitkan serta diperdagangkan semua surat-surat berharga yang bersifat jangka panjang, khususnya seperti obligasi dan maupun saham yang sebagaimana halnya seperti pasar uang maka sebuah pasar modal dapat diartikan di dalam ruang lingkup lokal regional dan maupun nasional oleh karena itu semua menyangkut dana-dana jangka panjang maka oleh karena itu pasar modal mengandung pengertian Modal ekonomi. Dana-dana yang dapat dihasilkan melalui penerbitan suatu instrument kredit yang di hasilkan di dalam dunia usaha dan maupun dunia perorangan yang di investasikan dalam persediaan ataupun dalam persediaan ataupun harta tetap.
Pasar modal berkembang mengikuti perkembangan teknologi. Teknologi informasi yang secara potensia yang juga merupakan suatu strategi, yang dalam artinya bahwa kekuatan Teknologi informasi juga merupakan suatu gambaran dari suatu strategi kompetitif yaitu perusahaan yang mengindikasikan kemampuan kompetisi baik melalui perubahan yang struktur industry. TI kini juga semakin marak dan banyak diperbincangkan karena yaitu diyakini bahwa dapat memberikan suatu keunggulan dalam suatu persaingan. Sebagai suatu perusahaan jasa perusahaan yang juga tergabung dalam industry Finance itu haruslah mampu mengikuti dalam mengikuti perkembangan TI ini.

Revolusi informasi juga kian melaju sejalan dengan adanya perkembangan ekonomi dan juga tidak ada satupun perusahaan yang dapat mampu menghindarinya. Perkembangan IT ini juga memiliki dampak positif dan yang negative bagi suatu dunia bisnis, yang salah satunya dirasakan antara lain adalah adanya suatu penurunan biaya serta juga perubahan pada proses dan juga pada transmisi informasi dalam suatu kegiatan bisnisnya.

Perkembangan TI pada era millennium ini memasuki siklus pertumbuhan yang memang secara mendunia, yaitu dimana konsekuensi dari perkembangan IT ini pada akhirnya yaitu memaksa manajemen untuk lebih meninjau kembali semua anggaran investasi mereka menjadi lebih besar dan 
memerlukan suatu improvisasi yang sangat tinggi.

Bagi suatu perusahaan modern, yang memiliki suatu strategi bisnis yang tidak saja cukup untuk menghadapi persaingan ini. Business plan harus pula juga dilengkapi oleh strategi TI. Tujuannya yaitu yang pasti untuk memanfaatkan secara optimum penggunaan TI sebagai suatu komponen utama sistem informasi yang ada di dalam suatu perusahaan

\section{Peran Dan Kewenangan Profesi Penunjang Pasar Modal Notaris Dalam Era Globalisasi}

Notaris juga merupakan salah satunya pejabat publik yang memiliki suatu wewenang untuk membuat akta kesepakatan kontrak atau keputusan yang diharuskan oleh hukum untuk dibuat dalam dokumen yang dikonfirmasi. Undang-undang yang mengatur tentang suatu jabatan notaris diatur dalam: UU No 30 Tahun 2004 tentang notaris yang berisi "notaris adalah merupakan suatu pejabat umum yang berwenang untuk hal dalam membuat suatu akta autentik dan maupun kewenangan lainnya" yang sebelumnya merupakan pergantian dari UU no 2 tahun 2014. Suatu Undang-undang Pasar Modal profesi notaris ini telah ditunjukkan sebagai salah satu profesi yang menjadi penunjang pasar modal. (Prana, 2018)

Kewenangan notaris diatur dalam UU Tahun 2004 nomor 30 Pasal 1 tentang kewenangan notaris itu yang berisi:

Notaris berwenang dalam membuat suatu akta autentik yang mengenai semua perbuatan, perjanjian, dan ataupun suatu ketetapan yang juga diharuskan oleh peraturan perundangundangan atau yang dikehendaki atau diinginkan oleh yang semua yang berkepentingan untuk dinyatakan di dalam akta autentik, dan untuk menjamin suatu kepastian tanggal di dalam suatu pembuatan akta, menyimpan akta, memberikan grosse, salinan, dan maupun kutipan akta, semuanya sepanjang pembuatan akta-akta itu tidak juga ditugaskan maupun dikecualikan kepada para pejabat lain ataupun orang lain yang ditetapkan oleh semua undangundang.

Peran yang utama di dalam suatu profesi penunjang pasar modal itu pada umumnya adalah untuk membantu suatu emiten di dalam suatu proses go publik dan yang memenuhi semua persyaratan mengenai hal keterbukaan yang bersifat terus menerus. (Prana, 2018)

Penunjukan Notaris sebagai profesi di dalam penunjang pasar modal dinyatakan di dalam, pasal 64 ayat 1 Undang-undang No 8 Tahun 1995 tentang pasar modal (UUPM), yang juga menyatakan bahwa profesi penunjang pasar modal itu terdiri dari:

1. Akuntan

2. Konsultan Hukum

3. Penilai

4. Notaris

5. Profesi lainnya yang ditetapkan

Era Globalisasi juga telah membawa dampak yang bersifat multi aspek karena berkaitan dengan bidang ekonomi hukum sosial dan politik dan keamanan. Kondisi ini membawa implikasi terhadap pertumbuhan dan perkembangan masyarakat menyangkut pemenuhan suatu kebutuhan masyarakat global, regional 
Elvira Fitriyani Pakpahan, Dkk: Peran Dan Kewenangan Profesi Penunjang Pasar...

dan nasional yang berdimensi kebersamaan berkelanjutan dan ketercakupan. (Soediro, 2017)

Pasar Modal memiliki fungsi yang strategis dan juga memilki pentingnya pasar modal membuat suatu pemerintah amat berkepentingan atas semua perkembangan dan juga kemajuan pasar modal, Karena juga berpotensi untuk menghimpun dana baik secara masif, sehingga dapat dimanfaatkan untuk memperbesar suatu volume pada kegiatan pembangunan. (Pakpahan, 2019)

Undang-undang No 8 Tahun 1995 Pasal 91 Tentang Pasar Modal juga menyebutkan:

"Setiap pihak itu dilarang untuk melakukan suatu tindakan baik dalam langsung maupun yang tidak langsung, dengan bertujuan untuk menciptakan suatu gambaran yang semua ataupun menyesatkan mengenai suatu kegiatan di dalam hal perdagangan, keadaan pasar, ataupun harga efek di Bursa Efek." (Prana, 2019)

Faktanya adalah pada semua perlindungan yang diberikan oleh hukum itu sebenarnya belum sepenuhnya dapat menjadi jaminan keamanan investor di dalam berinvestasi di dalam dunia pasar modal. Khususnya juga perlindungan itu mengenai keamanan saham para investor. (Wiyani, 2008) Sudah diketahui bahwa jika berinvestasi di pasar modal khususnya saham itu sangat mengandung resiko yang sangat tinggi. (Wiyani, 2008) Adapun pihak yang berkemungkinan melakukan pelanggaran dalam pasar modal adalah perusahaan publik ataupun

emiten dan juga para pihak-pihak yang memiliki posisi di dalam suatu perusahaan misalnya seperti Pemegang saham Utama, Direksi dan juga komisaris serta para profesional di dalam pasar modal, seperti: Penasehat Investasi, para Manajer Investasi, para Akuntan Publik, para Konsultan Hukum, Penilai, dan para Notaris. (Elvira Fitriyani Pakpahan, 2019)

\section{Benturan Kepentingan Bagi Konsultan Hukum Di Dalam Kejahatan Pasar Modal}

Pendapat hukum diperlukan untuk memperlihatkan kondisi dan keadaan perusahaan yang diperiksa dari segi hukum, seperti ketaatan terhadap sebuah ketentuan anggaran yang pada dasarnya dan peraturan perundang-undangan itu yang berlaku, perikatan-perikatan yang juga dilakukan, serta aset-aset yang dimiliki oleh para perusahaan maupun hal-hal yang dianggap sangat penting. (Wiyani, 2008)

Konsultan hukum dalam menjalankan profesinya harus tidak berpihak dan objektif, yang artinya konsultan hukum tersebut harus bebas dari pengaruh siapapun dan apapun. Oleh karena itu, seorang konsultan hukum tersebut tidak memiliki suatu saham ataupun tidak memiliki jabatan pada perusahaan tersebut. (Pakpahan, 2019)

Pekerjaan dari konsultan hukum adalah untuk kepentingan public maka sikap independen dan objektifnya harus diutamakan. Selain itu, konsultan hukum harus menghindari keadaan-keadaan yang dapat membuat pendapatnya diragukan 
oleh publik. Karena kepercayaan publik sangatlah penting bagi para peran seperti profesi konsultan hukum. Maka dikatakan konsultan hukum tetap bertindak professional dan menjaga independensinya. (Elvira Fitriyani Pakpahan S. F., 2019)

\section{SIMPULAN}

Sarana pasar modal merupakan sebagian satu dari banyaknya sektor perkembangan, namun di tengah pesatnya perkembangan ekonomi Pasar modal tidak berjalan dengan stabil sehingga memunculkan peluang terjadinya kejahatan dalam pasar modal. Pasar modal sendiri saat ini diawasi oleh OJK yang sebelumnya dikenal dengan BAPEPAM. Banyaknya kejahatan serta pelanggaran pasar modal, yang dimana kasusnya disebabkan karena luasnya pasar dalam pasar modal tersebut serta kurangnya efektifitas OJK dalam meminimalisir kejahatan-kejahatan dalam pasar modal itu sendiri , Meskipun dalam UUPM telah mencantumkan sanksi administratif baik perdata maupun pidana ,namun masih juga banyak terjadi kejahatan dalam pasar modal. Maka kesimpulannya adalah:

1. Notaris juga merupakan salah satu profesi yang dapat menjadi penunjang pasar modal, notaris yang hendak melaksanakan suatu kegiatan di dalam pasar memiliki suatu kemampuan dan juga pengetahuan di bidang pasar modal itu sendiri dan serta mendaftarkan diri pada pihak OJK. Di dalam pasar modal notaris itu berperan sebagai pejabat yang menjadi pembuat akta anggaran dasar dari para pihak yang juga terlibat di dalam pasar modal itu sendiri dan juga sebagai para pembuat perjanjianperjanjian yang berhubungan dengan suatu kegiatan di dalam pasar modal. Dalam proses go private, notaris juga berperan sebagai suatu pejabat yang memiliki wewenang di dalam pembuatan suatu akta perubahan anggaran dasar di perseroan.

2. Disimpulkan juga bahwa hubungan yang antara hukum dengan globalisasi itu memang sangatlah erat. Pada saat era globalisasi itu sudah diterima oleh banyak masyarakat, maka ia pun kemudian dapat berubah menjadi suatu hukum yang mengikat masyarakat itu.

3. Oleh karena itu disarankan untuk lebih menseleksi dengan baik terhadap apapun masuknya hal-hal di era globalisasi yang memang tidak sesuai dengan para jiwa dan kepribadian bangsa yang ada di dalam Indonesia karena pengaruh globalisasi itu yang tidak terseleksi dapat bisa menjadi suatu hukum yang mengikat.

\section{DAFTAR PUSTAKA}

Soediro, 2017, Hubungan Hukum dan Globalisasi: Upaya mengantisipasi dampak negatifnya, Vol 17 No 1, ISSN 1411-9781

Prana, R.P, 2019, Repertorium: Kenotariatan, Vol 8 No 1, Mei (2019) 
Elvira Fitriyani Pakpahan, Dkk: Peran Dan Kewenangan Profesi Penunjang Pasar...

Prana, R.P, 2018, peran notaris sebagai profesi penunjang pasar modal dalam upaya perlindungan hukum terhadap investor untuk menghindari kerugian akibat praktik manipulasi pasar di pasar modal, fakultas hukum studi magister kenotariatan, Universitas Sriwijaya.

Faisal. Santiago, April 2013, Peranan Notaris dalam Transaksi Saham Pada Pasar Modal Di Bursa Efek Jakarta, Vol 12 no 2,

Nasarudin, 2004, Dekan Fakultas Hukum Universitas Borobudur. Jakarta Timur

Makarim Edmon, 2011, Modernisasi hukum notaris masa depan ; Kajian Hukum Terdapat Kemungkinan Cybernotary Di Indonesia, Jurnal Hukum dan Pembangunan Tahun ke 41 No. 3.

Wiyani Wahyu, 2008, Meningkatkan Nilai Perusahaan melalui Investasi Teknologi Informasi, Jurnal Keuangan dan Perbankan, Vol 12, No. 2, Mei 2008, hal 240-252

Pakpahan, E.F., Sianipar, B.D., Angkasa, J., Sianturi, V.R., Hulu, S.R. (2019). Peran Pemerintah dalam Mitigasi Kejahatan Pasar Modal Indonesia. Journal of Educatio, Humaniora, and Social Sciences (JEHSS), 2 (1); 104-118

Pakpahan, E.F, Wijaya, S.F., Fortunata, A., Johny., Muhammad, H., (2019)
Benturan Kepentingan bagi Konsultan Hukum dalam Kejahatan Pasar Modal. Conflict of Interest for Legal Consultan in Capital Market Crime, Des 2019, hal 81

Undang-Undang Nomor 8 Tahun 1995

Tentang Pasar Modal Undang Undang Nomor 30 Tahun 2004 Tentang Jabatan Notaris

Bismar Nasution. 2001. Keterbukaan dalam Pasar Modal. Jakarta: Fakultas Hukum Universitas Indonesia, Cet. Pertama.

Hasan Zein Mahmud. 1998. Catatan Kolom Hasan Zein. Buku Pertama. Jakarta: Go Global Book.

Irsan Nasarudin dan Indra Surya. 2007. Aspek Hukum Pasar Modal Indonesia. Jakarta: Kencana Prenada Me-dia Group

Najib A. Gisymar. 1999. Insider Trading dalam Transaksi Efek. Bandung: Citra Aditya Bakti.

Soerjono Soekanto dan Sri Mamuji. 1984. Penelitian Hukum Normatif, Jakarta: Rajawali

Suharjono. 1995. Sekilas Tinjauan Akta Menurut Hukum. Jakarta: Sinar Grafika

Tan Thong Kie. 1994. Studi Notariat dan Serba-Serbi Praktek Notaris, Jakarta: Ichtiar Baru Van Hoeve.

Yahya Harahap, 2011. Hukum Perseroan Terbatas, Cet 3 Jakarta: Sinar Grafika. 